\title{
Conceptualization and Measurement of Market Orientation: A Review with a Roadmap for Future Research
}

\author{
Turkan Dursun \& Ceyhan Kilic \\ ${ }^{1}$ College of Business, West Texas A\&M University, Canyon, Texas, U.S.A. \\ ${ }^{2}$ College of Business Administration, Tarleton State University, Stephenville, Texas, U.S.A. \\ Correspondence: Türkan Dursun, College of Business, West Texas A\&M University, WTAMU Box 60890, \\ Canyon, TX 79016-0001 U.S.A.. Tel: 806-651-2506. E-mail: turkandursun@yahoo.com
}

Received: January 5, 2017

Accepted: January 25, 2017

Online Published: February 22, 2017

doi:10.5539/ijbm.v12n3p1

URL: https://doi.org/10.5539/ijbm.v12n3p1

\begin{abstract}
The purpose of this study is to review the existing research on the definition, conceptualization and measurement of market orientation and to provide guidance on the direction of future research in this area. Even though the number of research studies on market orientation has increased substantially, there is still no agreement among scholars regarding how to define market orientation, how broad its scope is, and how to measure it. Although the number of market orientation measurement scales has increased over the years, there is still limited research on how to differentiate between the various measures of market orientation. It is hoped that this review will provide researchers a deeper understanding of the scope of market orientation, help them select a suitable market orientation scale for their studies, and guide them in a more productive research path on the definition and measurement of market orientation.
\end{abstract}

Keywords: conceptualization, literature review, market orientation, measurement scale

\section{Introduction}

As the importance of market orientation is acknowledged by growing numbers of academicians and practitioners, increasing research efforts have been directed to measurement issues pertaining to market orientation. A number of marketing scholars have devoted their attention to identifying the major domains of the market orientation construct and developing more reliable and valid measures of it (e.g., Atuahene-Gima, 1995; Deng \& Dart, 1994; Deshpandé \& Farley, 1996; Dong, Zhang, Hinsch, \& Zou, 2016; Gyepi-Garbrah \& Asamoah, 2015; Homburg \& Pflesser, 2000; Jaworski \& Kohli, 1993; Jangl, 2016; Kohli, Jaworski, \& Kumar, 1993; Matsuno \& Mentzer, 2000; Matsuno, Mentzer, \& Rentz, 2005; Modi, 2012; Modi \& Mishra 2010; Narver \& Slater, 1990). In spite of the growing number of research studies on market orientation, there is still no consensus among researchers about the definition of market orientation and how to measure it (Matsuno et al., 2005). Even though the number of the market orientation scales has increased over the years, there is little research on how to differentiate between the various scales of market orientation. This study aims to review the extant research on the definition, conceptualization and measurement of market orientation and to provide a roadmap on the direction of future research in this area. It is hoped that this review will help researchers better understand the scope of market orientation, choose an appropriate market orientation scale for their studies, and follow a more productive path for future research on the definition and measurement of market orientation.

\section{Definition and Conceptualization of Market Orientation}

A significant volume of conceptual research on market orientation has discussed such descriptive issues as how to install a strong market orientation or market-oriented thought and behavior within an organization (e.g., Day, 1990, 1994, 1998; Hunt \& Morgan, 1995; Jaworski \& Kohli, 1993; Ruekert, 1992). A number of scholars have offered different definitions and conceptualizations of market orientation (e.g., Deshpandé, Farley, \& Webster, 1993; Kohli \& Jaworski, 1990; Narver \& Slater, 1990). Throughout the literature a variety of terms have been used interchangeably to address a market orientation. The terms market-oriented, market-driven (Day, 1994; Deshpandé et al., 1993), customer orientation (Deshpandé \& Farley, 1998, 1999; Shapiro, 1988; Webster, 1988), customer focus (Deshpandé \& Farley, 1998, 1999), customer-focused, customer-oriented, and customer-centric are often used synonymously. "Close to the customer" has been a key term to express a market orientation 
(Caruana, Ramaseshan, \& Ewing, 1998; Peters \& Waterman, 1982; Shapiro, 1988; Webster, 1988). Narver and Slater (1990) and Kohli and Jaworski (1990) have chosen to use the term "market orientation" over the terms "the marketing concept" or "marketing orientation" in their articles.

Many scholars have presented their views on which term is more appropriate to use to address a market orientation. Sargeant and Mohamad (1999) argued that the term market orientation seems to be more appropriate since it is "less politically charged and does not inflate the importance of the marketing function in the organization" (Sargeant \& Mohamad, 1999, p.44). The term market orientation implies that marketing is the responsibility of the all functional units in the organization, not just the marketing function (Sargeant \& Mohamad, 1999). According to Slater and Narver (1994b, 1998), market orientation and marketing orientation are entirely different concepts. To the authors, a marketing orientation refers to "an emphasis on the marketing function" (p.24). Caruana et al. (1998) believed that a marketing orientation refers to the specific activities of the marketing department or division. Under a marketing orientation, the marketing function gains importance and is placed at the top of a hierarchical structure in the organization. Traditional marketing activities gain importance even though they are not major or appropriate core capabilities of the firm. Such an overemphasis on and empowerment of one functional area in the organization automatically leads to interdepartmental conflicts over issues like resource allocation and business priorities (Slater \& Narver, 1994b). Therefore, using a marketing orientation as synonymous with a market orientation is misleading, given the fact that "Customer value is created by core capabilities throughout the entire organization" (Slater \& Narver, 1994b, p.24). The scope of a market orientation is broader than that of a marketing orientation.

According to Deshpandé and Webster (1989), Shapiro (1988), and Slater and Narver (1995), the terms 'market-oriented', 'market driven', and 'customer focused' are synonymous. Day (1998) stated that "a strong market orientation is embedded deeply in the genetic make-up of a market-driven organization" (p.8). Day (1994) argued that "organizations can become more market oriented by identifying and building the special capabilities that set market-driven organizations apart" (p.38). Furthermore, according to Day (1998, p.8), there are seven distinctive behavior and capabilities of a market-driven organization: (1) offering superior solutions and experiences, (2) focusing on superior customer value, (3) converting satisfaction to loyalty, (4) energizing and retaining employees, (5) anticipating competitors' moves, (6) viewing marketing as an investment, not a cost, and (7) nurturing and leveraging brands as assets. These behaviors and capabilities are also associated with a market orientation. Day $(1994,1998)$ used the term "market-driven" to define an organization with a strong market orientation. Based on the arguments offered by Day (1994, 1998), being market-driven can be considered either the same as a market orientation or a crucial component of a market orientation. In either case, it is appropriate to say that the arguments made related to market-driven organizations apply largely to market-oriented organizations as well.

On the other hand, Jaworski and Kohli (1996) argued that the terms market-oriented, market-driven, and customer-oriented do not share the same meaning, and are not synonymous. The term market orientation focuses on a larger set of market forces and stakeholders, not only customers. Whereas, the term customer orientation emphasizes a focus on customers. In a commentary of Christensen and Bower's (1996) study, Slater and Narver (1998) underscored the distinctions between the two types of customer orientation. These are a customer-led philosophy and a market-oriented philosophy. These are often confused with each other. A customer-led business is likely to be reactive, have a short-term focus, emphasizes customers' expressed wants/needs, and customer satisfaction (Slater \& Narver, 1998). On the other hand, a market-oriented business is prone to act proactively, to adopt a long-term orientation, to understand and satisfy customers' both expressed and latent wants/needs, and to emphasize customer value (Slater \& Narver, 1998).

A comprehensive examination of the current literature on market orientation reveals that there has been no consensus among scholars on the definition of market orientation. Marketing scholars have not reached a complete agreement on what constitutes to a market orientation. The debate on this issue is ongoing (Cadogan, Diamantopoulos, \& Mortanges, 1999; Caruana et al., 1998; Matsuno et al., 2005). According to Siguaw, Simpson, and Baker (1998), for the most part, different definitions of market orientation have mainly been developed from different conceptualizations of the marketing concept. Therefore, it is possible that the variations in the definitions of a market orientation can be reflective of the diverse perspectives that have been adopted over time to define the marketing concept (Siguaw et al., 1998).

A market orientation has been seen as the implementation of the marketing concept (e.g., Kohli \& Jaworski, 1990), that is considered as a business philosophy, an ideal or a policy statement (Barksdale \& Darden, 1971; Kohli \& Jaworski, 1990; McNamara, 1972). More comprehensive, informative definitions of market orientation were suggested by Kohli and Jaworski (1990), and Narver and Slater (1990). These definitions have been 
widely-accepted and frequently-cited by marketing scholars throughout the literature. Kohli and Jaworski (1990) offered a formal operational definition of a market orientation as follows: "Market orientation is the organization-wide generation of market intelligence pertaining to current and future customer needs, dissemination of the intelligence across departments, and organization-wide responsiveness to it" (p.6). Kohli and Jaworski (1990) attempted to delineate the domain of the market orientation construct through a comprehensive model. Their definition of the market orientation concept is based on a field research conducted through in-depth interviews with 62 managers in four U.S. cities. The results indicated that, without exception, the managers interviewed agreed that a customer focus is the central element of a market orientation. For many practitioners, a customer orientation did not mean just the collection of customer information concerning their needs and preferences through customer research. Indeed, it meant the gathering of market intelligence that is based on information about exogenous factors affecting customer wants and needs, and information about current and future needs of customers (Kohli \& Jaworski, 1990). This is an indication of the fact that practitioners have a long-term-oriented view on market orientation. Moreover, market orientation is not seen solely as a responsibility of the marketing department. Interestingly, the idea that profitability is a component of market orientation is not supported by the field findings. Rather, all viewed profitability as a consequence of a market orientation, not as a part of it (Kohli \& Jaworski, 1990). Narver and Slater (1990) viewed market orientation as follows: "the organization culture that most effectively and efficiently creates the necessary behaviors for the creation of superior value for buyers and, thus, superior performance for the business" (p.21). Narver and Slater (1990) suggested customer orientation, competitor focus, and cross-functional coordination as the three pillars of market orientation. These pillars were characterized as being long-term in vision and profit-driven (Narver \& Slater, 1990). Deshpandé et al., (1993) saw customer orientation as synonymous with a market orientation since they accepted a traditional definition of a market, that is, "the set of all potential customers of a firm" (p.27). They defined customer orientation as "the set of beliefs that puts the customer's interest first, while not excluding those of all other stakeholders such as owners, managers, and employees, in order to develop a long-term profitable enterprise" (p.27; Also see Jaworski \& Kohli, 1996, p.120). This view of a market orientation (or customer orientation) is consistent with the three components of a market orientation suggested by Narver and Slater (1990) with the exception of a competitor orientation. In other words, Deshpandé et al.'s (1993) definition of a market orientation reflects both the contents of customer orientation and interfunctional coordination defined by Narver and Slater (1990). Deshpandé and Farley (1996) defined market orientation according to the content of their parsimonious 9-item market orientation scale developed from the three existing scales through a comprehensive meta-analysis procedure. They briefly defined market orientation as: "the set of cross-functional processes and activities directed at creating and satisfying customers through continuous needs-assessment" (p.14; Also see Deshpandé \& Farley, 1998, p.213; Deshpandé \& Farley, 1999, p.112).

According to Kohli and Jaworski (1990), a market-oriented organization is one whose actions are consistent with the marketing concept. In other words, a market-oriented or market-driven organization is the one in which the three pillars of the marketing concept (customer focus, coordinated marketing, and profitability) are successfully implemented (Kohli \& Jaworski, 1990). However, Hunt and Morgan (1995) argued that market orientation "is not the same thing as, nor a different form of, nor the implementation of, the marketing concept. Rather, it would seem that a market orientation should be conceptualized as supplementary to the marketing concept" (p.34). They proposed that: "a market orientation is (1) the systematic gathering of information on customers and competitors, (2) the systematic analysis of the information for the purpose of developing market knowledge, and (3) the systematic use of such knowledge to guide strategy recognition, understanding, creation, selection, implementation, and modification.” (Hunt \& Morgan, 1995, p.1; Wrenn, 1997, p.34). Finally, Day (1994) viewed market orientation as a set of excellent skills by stating that "market orientation represents superior skills in understanding and satisfying customers" (p.37; Day, 1990; Also see Jaworski \& Kohli, 1996, p.120). Table 1 presents five different definitions of market orientation offered by scholars and the comparisons of these definitions.

Table 1. Definitions of market orientation and their comparisons

\begin{tabular}{|c|c|}
\hline Author & Definition \\
\hline $\begin{array}{ll}\text { (1) Kohli } & \text { and } \\
\text { Jaworski (1990) } & \end{array}$ & $\begin{array}{l}\text { "Market orientation is the organization-wide generation of market intelligence } \\
\text { pertaining to current and future customer needs, dissemination of the intelligence } \\
\text { across departments, and organization-wide responsiveness to it" (p.6). }\end{array}$ \\
\hline
\end{tabular}


(2) Narver and Slater (1990)

(3) Deshpandé et at. (1993)

(4) Day (1994)

(5) Deshpandé Farley (1996)
Market orientation is "the organization culture that most effectively and efficiently creates the necessary behaviors for the creation of superior value for buyers and, thus, superior performance for the business" (p.21).

al. Customer orientation (or market orientation) is "the set of beliefs that puts the customer's interest first, while not excluding those of all other stakeholders such as owners, managers, and employees, in order to develop a long-term profitable enterprise" (p.27).

Market orientation is a set of excellent skills by stating that "market orientation represents superior skills in understanding and satisfying customers" (p.37).

and Market orientation is "the set of cross-functional processes and activities directed at creating and satisfying customers through continuous needs-assessment" (p.14).

\section{Comparison of Market Orientation Definitions (1), (2), and (3) by Day (1994, p.37)}

Each definition represents principal features of a market orientation and complements each other:

1) A set of beliefs that puts the customer's interests first (Deshpandé, Farley, and Webster 1993).

2) The ability of the organization to generate, disseminate, and use superior information about customers and competitors (Kohli and Jaworski 1990).

3) The coordinated application of interfunctional resources to the creation of superior customer value (Narver and Slater 1990).

\section{Comparison of Market Orientation Definitions (1), (2), (3), and (4) by Jaworski and Kohli (1996, p.121)}

\section{Similarities:}

1) All maintain an external focus.

2) In all definitions, the central focus is the customer.

3) All definitions suggest a broader focus that include not only customers but also some other influential forces, such as competitors, technology, regulation, and other stakeholders.

4) All definitions accept the importance of being responsive to customer needs and wants.

\section{Differences:}

1) Each definition is based on one of the two alternative perspectives on market orientation: (a) a behavioral/activities/process perspective (Day, 1994; Kohli \& Jaworski, 1990), versus (b) a cultural perspective (Deshpandé et al., 1993; Narver \& Slater, 1990).

2) The terms market-oriented, market-driven, and customer-oriented do not share the same meaning.

\subsection{Comparisons of Definitions and Conceptualizations of Market Orientation}

Some scholars have tried to identify the similarities and differences among these definitions (e.g., Day, 1994; Jaworski \& Kohli, 1996). Table 1 presents the comparisons of five definitions of market orientation made by scholars. According to Day (1994), the different definitions of market orientation suggested by Deshpandé et al. (1993), Kohli and Jaworski (1990), and Narver and Slater (1990) are not alternative to each other rather they complement each other. He believed that each of the four definitions of market orientation represents principal features of a market orientation (p.37, in smaller fonts): (1) a set of beliefs that puts the customer's interests first (Deshpandé et al., 1993), (2) the ability of the organization to generate, disseminate, and use superior information about customers and competitors (Kohli \& Jaworski, 1990), and (3) the coordinated application of interfunctional resources to the creation of superior customer value (Narver \& Slater, 1990). Similarly, Jaworski and Kohli (1996) analyzed the four different definitions of a market orientation, suggested by Day (1994), Deshpandé et al. (1993), Kohli and Jaworski (1990), and Narver and Slater (1990), and determined the similarities and differences among these definitions. They identified four similarities among the four well-known 
definitions (p.121): First, all maintain an external focus. Second, in all definitions, the central focus is the customer. Third, all definitions suggest a broader focus that include not only customers but also some other influential forces, such as competitors, technology, regulation, and other stakeholders. Fourth, all definitions accept the importance of being responsive to customer needs and wants. They recognized two differences among the definitions (p.121). First, each definition is based on one of the two alternative perspectives: (1) a behavioral/activities/process perspective versus (2) a cultural perspective. Day (1994), and Kohli and Jaworski (1990) adopted the former perspective while Deshpandé et al. (1993), and Narver and Slater (1990) followed the latter in their definitions. Second, Jaworski and Kohli (1996) believed that the terms market-oriented, market-driven, and customer-oriented do not share the same meaning. The term market orientation concentrates on a larger set of market forces and stakeholders, not only customers, while the term customer orientation emphasizes only customers.

\subsection{Arguments on Broadening the Scope of Market Orientation}

In the market-driven era, the market has the "pivotal role" in the design, development, and implementation of new organizational strategies and in the discard of the old ones (Cravens, 1998, p.237; Cravens, Greenley, Piercy, \& Slater, 1998; Day, 1994). Developing effective new market strategies can create great opportunities for businesses. Designing market strategies on the basis of a reactive stance and/or a proactive stance can significantly affect the success of businesses (Baker \& Sinkula, 1999; Chandy \& Tellis, 1998; Narver, Slater, \& MacLachlan, 2004). Some studies have stressed the importance of a proactive stance for businesses and the need for broadening the scope of a market orientation to include proactive responsiveness or market insight or the driving markets concept as an integral part of it (e.g., Chandy \& Tellis, 1998; Jaworski \& Kohli, 1996; Jaworski, Kohli, \& Sahay, 2000; Narver et al., 2004).

Several scholars have contended that the scope of a market orientation is actually broader than that previously defined (e.g., Jaworski \& Kohli, 1996; Jaworski et al., 2000). Jaworski et al. (2000) criticized the literature for defining a market orientation as an approach that mainly focuses on existing or current customer needs/preferences and market structure (customer-led). They believe that this would be a narrow conceptualization of a market orientation. Indeed, a market orientation is more than that and aims to proactively shape the customer preferences and/or the market structure rather than accepting them as given. Market/industry foresight or proactiveness has been viewed as an extremely crucial, subset element of being market-oriented by Jaworski and Kohli (1996). Jaworski and Kohli (1996, p.126) defined market foresight as "a strategic orientation to market that moves beyond the short-term current customers and competitors to the broader forces that shape markets." In another definition, industry foresight has been referred to "an organization's ability to anticipate and perhaps even shape the evolution of markets" (Also see Hamel \& Prahalad, 1994; Jaworski \& Kohli, 1996, p.125). Obviously, market or industry foresight broadens the concept of market orientation. Thus, a market orientation is characterized by not only a reactive position but also a proactive position towards markets.

\section{Measures of Market Orientation}

Some earlier studies highlighted various measurement concerns of scholars (See Lawton \& Parasuraman, 1980; McNamara, 1972) regarding the marketing concept or a market orientation. However, most of the time, the primary focus of these studies was not to develop a measurement scale. Therefore, the measures they utilized were not developed on the basis of systematical procedures for scale development (Kohli et al., 1993). Rather, the earlier studies on the adoption of the marketing concept often relied on very simple measures (Deng \& Dart, 1994).

\subsection{Review of Major Market Orientation Scales}

The utilization of a multi-item measure of market orientation is quite new in the literature. Kotler (1977) can be regarded as the one of the earliest scholars that attempted to define the domain of market orientation and to measure it. Kotler (1977) developed a marketing effectiveness audit or scale that can be used by managers in assessing how well their organization understands and implements marketing. He used a questionnaire or audit to measure the level of marketing effectiveness. He measured marketing effectiveness through five dimensions: Consumer philosophy, integrated marketing organization, adequate marketing information, strategic orientation, and operational efficiency. These dimensions are closely linked to the dimensions of market orientation such as customer orientation, competitor orientation, cross-functional coordination (Narver \& Slater, 1990), and market intelligence generation (Kohli \& Jaworski, 1990). Even though the domains of the two concepts, marketing effectiveness and market orientation, may not overlap perfectly in every aspect, they are definitely closely related to one another. According to Au and Tse (1995) and Tse (1998), the major pitfall of the questionnaire used by Kotler (1977) was the wording of the questions. Since the questionnaire was intended to be used for 
self-evaluation, the questions were asked in a direct manner rather than in an indirect manner. As a result, it was possible that respondents were more likely to give socially desirable responses rather than true responses in a large scale survey (Au \& Tse, 1995; Tse, 1998). In spite of its apparent limitation, the marketing effectiveness audit can be considered as one of the first steps toward developing multi-dimensional, more reliable measures of market orientation.

To the authors' best knowledge, the earliest, reliable, comprehensive, multi-item measures of market orientation were developed by Narver and Slater (1990) and Jaworski and Kohli (1993). These scholars have also developed clear and precise definitions of the domain of the market orientation construct. Both Jaworski and Kohli (1993) and Narver and Slater (1990) developed these scales as parts of their empirical studies focusing on the market orientation-organizational performance relationship. These two scales are widely-recognized by scholars and frequently-used in empirical studies pertaining to market orientation.

Narver and Slater (1990) conceptualized a market orientation and developed a valid, reliable measure of market orientation which is labeled as MKTOR. MKTOR is a scale that measures the level of market orientation. Market orientation was conceptualized as having three behavioral components (customer orientation, competitor orientation and interfunctional coordination) and two decision criteria (long-term focus and profitability). In order to develop a measure of market orientation and test the proposed model, 440 respondents in 140 forest product divisions or strategic business units (SBUs) of a major Western corporation were surveyed. They found evidence of the construct validity for the three-component model of a market orientation. These components were customer orientation, competitor orientation, and interfunctional coordination. Long-term focus and profitability were simply disregarded.

Kohli, Jaworski, and Kumar (1993) believe that the scale proposed by Narver and Slater (1990) is closely associated with Day and Wensley's (1988) conceptualization which is based on competitor-orientedness, customer-orientedness, and inter-functional coordination. Narver and Slater's (1990) conceptualization of market orientation closely parallels to Kohli and Jaworski's (1990) conceptualization. Three behavioral components (i.e., customer orientation, competitor orientation, and interfunctional coordination) suggested by Narver and Slater (1990) involve intelligence generation, dissemination, and managerial action. This scale has certain advantages. First, the scale was developed at the SBU level, not at the corporate level. This feature of MKTOR makes this scale more operational and also largely applicable to both a single organization and an organization with multiple SBUs. A small group of scholars have argued that market orientation should be evaluated at the SBU level since the levels of market orientation within separate SBUs of the same corporation can vary significantly (e.g., Kohli \& Jaworski, 1990; Ruekert, 1992). Furthermore, Workman, Homburg, \& Gruner (1998, p.26) suggested that marketing processes/activities are mostly performed at the SBU/divisional level. Second, MKTOR can serve as a good diagnostic tool in organizations in measuring the level of a market orientation. However, MKTOR has two limitations. First, MKTOR was based on the data obtained from many SBUs of a single corporation in a specific business area (i.e., forest products divisions). This characteristic of the sample may restrict the generalizability of this scale. Second, even though this scale is based on a cultural perspective of market orientation, its content is more reflective of behavioral aspects of a market-oriented culture. Homburg and Pflesser (2000) noted that the earlier studies that adopted a cultural perspective of market orientation have generally utilized behavioral measures to assess market orientation. These studies have given little consideration to foundational, underlying elements of a market-oriented culture (Homburg \& Pflesser, 2000). This observation also seems to be true for the MKTOR scale. MKTOR has been used in the development of some other market orientation scales (e.g., Cadogan et al., 1999; Deng \& Dart, 1994; Deshpandé \& Farley, 1996; Gray, Matear, Boshoff, \& Matheson, 1998). It has also been used by a large number of studies as a measurement instrument (e.g., Deshpandé \& Farley, 1999; Greenley, 1995; Han, Kim, \& Srivastava, 1998; Maignan, Ferrell, \& Hult, 1999; Menguc, 1996; Siguaw, Brown, \& Widing, 1994; Slater \& Narver, 1994a).

Jaworski and Kohli (1993) empirically tested and validated a theoretical framework of a market orientation which they suggested in their 1990 study. The primary objective of this study was to investigate the antecedents and consequences of a market orientation. They utilized a complex sampling method involving two separate samples. The first sample was drawn from the member companies of the Marketing Science Institute (MSI) and the top 1000 companies (in sales revenues) included in the Dun and Bradstreet Million Dollar Directory. In order to cross-validate the findings from the first sample, data were obtained from a second sample. They used the American Marketing Association membership roster as the sampling frame for the second sample. As a result, the authors developed a 32-item and four-dimension market orientation scale with good reliability scores. Jaworski and Kohli (1993) with this study developed a clear definition of a market orientation, identified the domain of the market orientation construct, and designed a widely-used measurement scale of a market 
orientation. This measure of market orientation is based on the behavioral perspective of market orientation. It is the origin of the MARKOR scale. This scale has been utilized in the construction of a number of market orientation scales (e.g., Cadogan et al., 1999; Deshpandé \& Farley, 1996; Gray et al., 1998; Kohli et al., 1993; Matsuno \& Mentzer, 2000). Based on the high value of the coefficient alpha for each dimension, this scale can be regarded as a reliable instrument to evaluate the level of market orientation. The inclusion of diverse businesses in the sample and the use of a multiple-informant (marketing executive versus nonmarketing executive) approach in data collection are some of the positive properties of this study that add value to the associated scale. Additionally, the comprehensive nature of the sampling procedure used in this study contributes to the overall reliability of the scale. This scale allows the measurement of market orientation at the business unit level. In this regard, it is as appropriate as the MKTOR scale. However, this scale is longer than the MKTOR scale. The length of this scale may be somewhat cumbersome for researchers and even for practitioners. Given the observation that the current trend in research is apparently towards developing more parsimonious measures of market orientation, the length of the scale might make it less favorable among researchers despite its advantages.

Kohli and Jaworski (1990), Jaworski and Kohli (1993), and Kohli et al. (1993) defined a market orientation, as mentioned earlier, as the organization-wide generation of market intelligence pertinent to current and future needs/preferences of customers, dissemination of this intelligence across the various departments vertically and horizontally in the organization, and organizational responsiveness to this intelligence. Kohli et al. (1993) aimed to develop a valid and reliable measure of market orientation. Based on the four domains of market orientation suggested by Kohli and Jaworski (1990), and Jaworski and Kohli (1993), the authors proposed a 20-item market orientation scale and assessed the psychometric properties of this measure. This market orientation scale was labeled as MARKOR. The distinguishing feature of their study is the implementation of a strict systematic procedure for the scale development. This measure possesses some important characteristics (Kohli et al., 1993). First, it has a focus on all market forces including customers and the forces that drive customer needs and preferences and competitive actions. Second, it includes activity-based items rather than business philosophy. Third, it is a combination of a general market orientation factors and related component factors. Finally, MARKOR has managerial significance since the suggested scale is assessed and developed at the SBU level. It enables an organization to assess their progress toward market orientedness at a SBU level and for all of its SBUs. It helps an organization accomplish target market orientation levels which are feasible for the organization (Kohli et al., 1993) and identify problem areas in each component of market orientation. According to Kohli et al. (1993), the proposed measurement scale is closely associated with Dickson's (1992) view of competitive rationality. This study can be viewed as a comprehensive extension of the scale work done by Kohli and Jaworski (1993). The MARKOR scale was used by Homburg and Pflesser (2000), Matsuno and Mentzer (2000), and Siguaw, Simpson, and Baker $(1998,1999)$.

Some other researchers have also attempted to develop market orientation scales. But, these scales are relatively less known (e.g., Cadogan et al., 1999; Deng \& Dart, 1994; Deshpandé \& Farley, 1996; Gray et al., 1998; Gyepi-Garbrah \& Asamoah, 2015; Lado, Maydeu-Olivares, \& Rivera, 1998; Matsuno \& Mentzer, 2000; Matsuno et al., 2005; Ruekert, 1992). Most of the market orientation scales developed over the last two decades (e.g., Cadogan et al., 1999; Deng \& Dart, 1994; Deshpandé \& Farley, 1996; Matsuno \& Mentzer, 2000) have been based on or originated from the two widely used scales discussed above (MKTOR and MARKOR). More recently, Gyepi-Garbrah and Asamoah (2015) proposed a holistic measurement scale of internal market orientation (IMO) which consists of the following three dimensions: Responsiveness to information, dissemination of information, and internal information generation. Their study was conceptual and the scale was not tested.

Table 2 provides a brief review of main studies pertinent to measurement issues on market orientation

\begin{tabular}{lllll}
\hline Author & Primary Purpose & Sample Characteristics & Dimension(s) & Scale Characteristics \\
\hline Kotler (1977) & To develop marketing & Customer & Marketing Effectiveness Audit. \\
& effectiveness audit or & Philosophy, & 15-item (each item was \\
& scale that can be used & Integrated Marketing & designed in the form of a \\
& by managers in & Organization, & question). \\
& assessing how well --- & Adequate Marketing & 3-point scale (each scale was \\
& their organization & Information, & given a score of 0, 1, and 2, \\
& understands and & Strategic Orientation, &
\end{tabular}




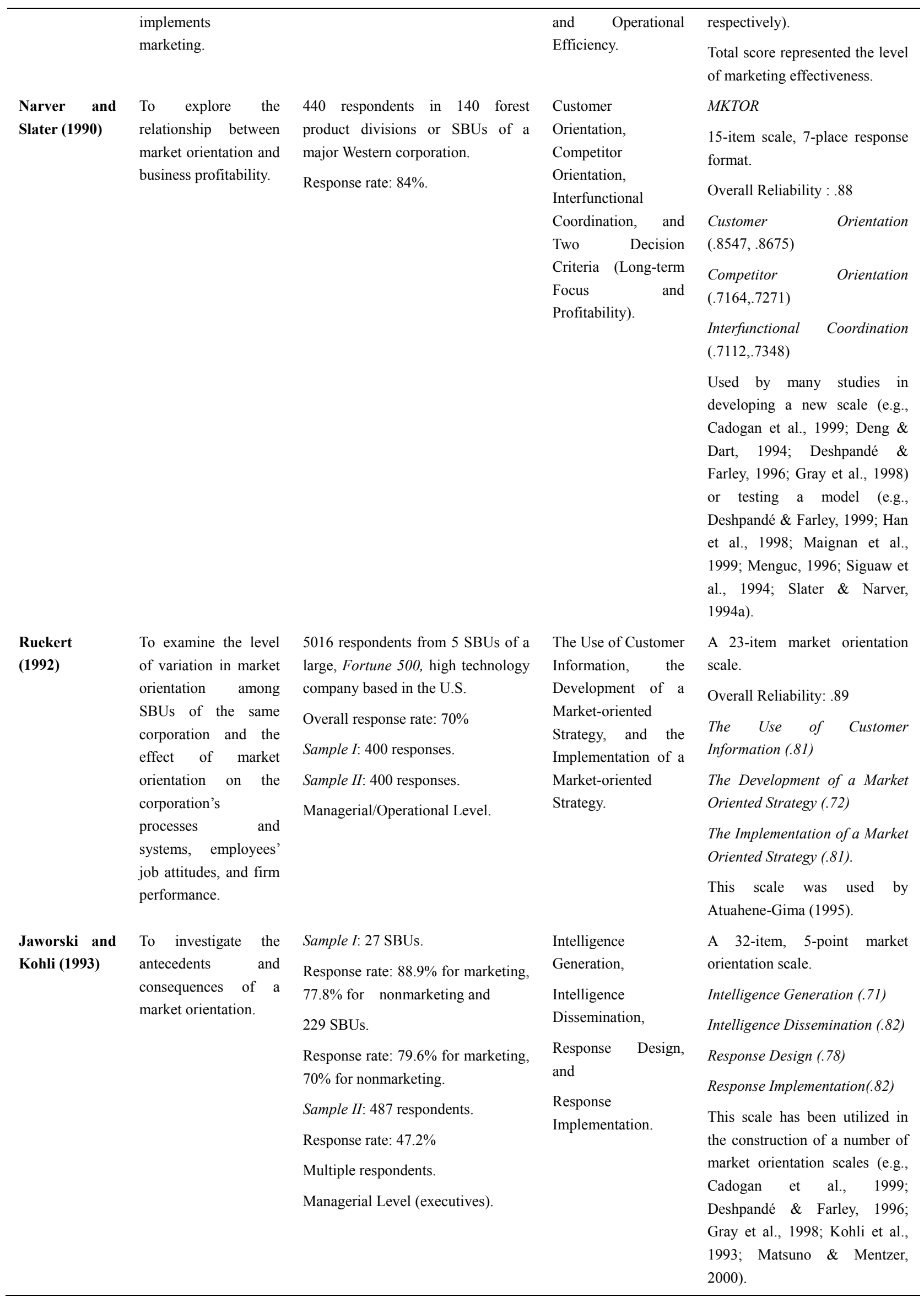




\begin{tabular}{|c|c|c|c|c|}
\hline $\begin{array}{l}\text { Kohli et al. } \\
\text { (1993) }\end{array}$ & $\begin{array}{l}\text { To develop a valid and } \\
\text { reliable measure of } \\
\text { market orientation } \\
\text { based on the four } \\
\text { domains of market } \\
\text { orientation suggested } \\
\text { by Kohli and Jaworski } \\
\text { (1990), and } \\
\text { Jaworski and Kohli } \\
\text { (1993). }\end{array}$ & 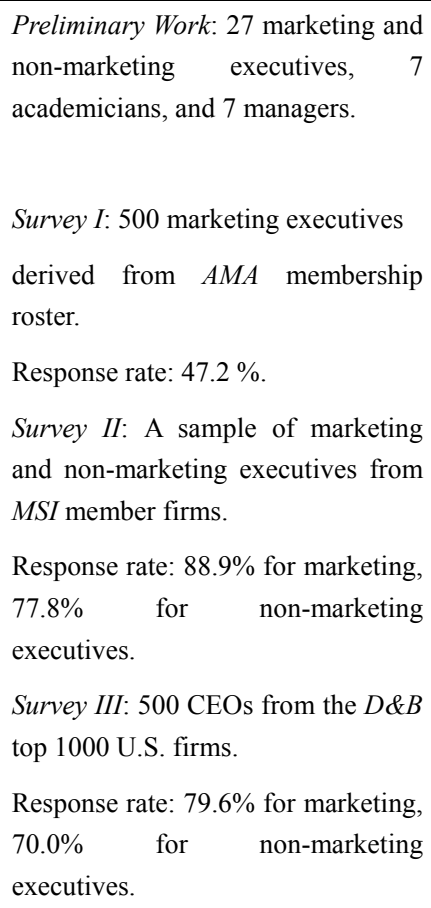 & $\begin{array}{l}\text { Intelligence } \\
\text { Generation, } \\
\text { Intelligence } \\
\text { Dissemination, and } \\
\text { Responsiveness. }\end{array}$ & $\begin{array}{l}\text { MARKOR } \\
\text { A 20-item scale, 5-place } \\
\text { response format. } \\
\text { Overall Reliability: } \\
\text { (reported by Deshpandé and } \\
\text { Farley 1996). } \\
\text { A strict systematic procedure for } \\
\text { the scale } \\
\text { development was used. } \\
\text { This scale has been used by a } \\
\text { number of studies (e.g., } \\
\text { Homburg \& Pflesser, 2000; } \\
\text { Matsuno \& Mentzer, 2000; } \\
\text { Siguaw et al., 1998, 1999). }\end{array}$ \\
\hline $\begin{array}{l}\text { Deshpandé et } \\
\text { al. (1993) }\end{array}$ & $\begin{array}{l}\text { To test the impact of } \\
\text { corporate culture, } \\
\text { innovation, and } \\
\text { market orientation on } \\
\text { company } \\
\text { performance. }\end{array}$ & $\begin{array}{l}\text { A sample of } 138 \text { Japanese } \\
\text { executives. }\end{array}$ & $\begin{array}{l}\text { Customer } \\
\text { Orientation. }\end{array}$ & $\begin{array}{l}\text { Customer Orientation Scale } \\
\text { A 9-item scale, 5-place } \\
\text { Likert-type agreement response } \\
\text { format. } \\
\text { Overall Reliability: .71. } \\
\text { This scale has been used by a } \\
\text { number of studies (e.g., Baker, } \\
\text { Simpson, \& Siguaw, 1999; } \\
\text { Deshpandé \& Farley, 1999; } \\
\text { Steinman, Deshpandé, \& Farley, } \\
\text { 2000). }\end{array}$ \\
\hline $\begin{array}{l}\text { Deng and Dart } \\
\text { (1994) }\end{array}$ & $\begin{array}{l}\text { To develop a reliable } \\
\text { and } \\
\text { measurement scale of } \\
\text { market orientation that } \\
\text { is applicable to a wide } \\
\text { range of business } \\
\text { firms. }\end{array}$ & $\begin{array}{l}\text { Preliminary Work: a panel of } \\
\text { professors and graduate students of } \\
\text { marketing. } \\
\text { Senior managers of local firms. } \\
\text { Survey: a sample of } 248 \text { Canadian } \\
\text { companies. } \\
\text { Response rate: } 49.6 \% \\
\text { General/Marketing Manager Level. }\end{array}$ & $\begin{array}{l}\text { Customer } \\
\text { Orientation, } \\
\text { Competitor } \\
\text { Orientation, } \\
\text { Interfunctional } \\
\text { Coordination, and } \\
\text { Profit Orientation. }\end{array}$ & $\begin{array}{l}\text { A 5-point interval rating scale. } \\
\text { Customer Orientation (.78) } \\
\text { Competitor Orientation (.73) } \\
\text { Interfunctional Coordination } \\
\text { (.77) } \\
\text { Profit Emphasis (.75) } \\
\text { A procedural approach for the } \\
\text { development of the scale was } \\
\text { followed. This scale was utilized } \\
\text { by Gray et al. (1998) in } \\
\text { developing a new scale. }\end{array}$ \\
\hline $\begin{array}{l}\text { Pelham and } \\
\text { Wilson (1995) }\end{array}$ & $\begin{array}{l}\text { To explore the } \\
\text { relationship between } \\
\text { market orientation and } \\
\text { firm performance. }\end{array}$ & $\begin{array}{l}\text { Longitudinal data for 1992-1993 } \\
\text { from a sample of } 68 \text { small Michigan } \\
\text { firms from a variety of industries. } \\
\text { The data obtained from a university } \\
\text { database. } \\
\text { Top Management Level. }\end{array}$ & $\begin{array}{l}\text { Customer } \\
\text { Understanding } \\
\text { Orientation, } \\
\text { Customer } \\
\text { Satisfaction } \\
\text { Orientation, and } \\
\text { Competitor } \\
\text { Orientation. }\end{array}$ & $\begin{array}{l}\text { A 9-item scale. } \\
\text { Overall Reliability: } .92 \text {. } \\
\text { Originally developed by Pelham } \\
\text { (1993), based on the measures } \\
\text { suggested by Narver and Slater } \\
\text { (1990), and Jaworski and Kohli } \\
\text { (1993). }\end{array}$ \\
\hline
\end{tabular}




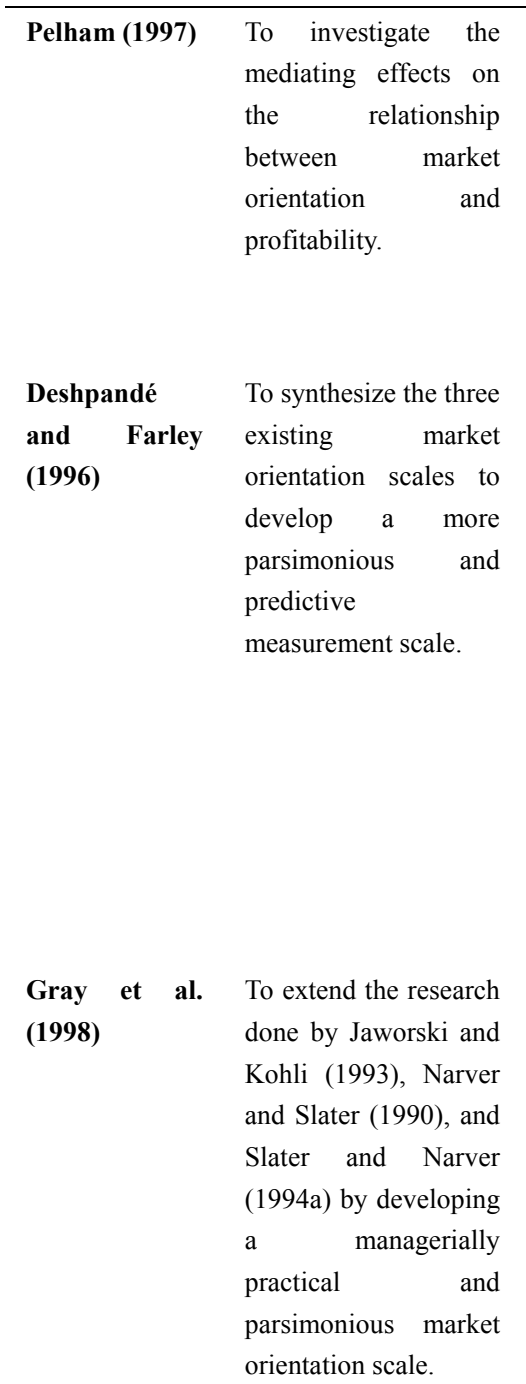

Lado et al. To propose a precise, (1998)
A sample of 160 industrial firms.

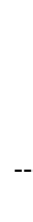

A conveniently-derived multinational sample of 82 marketing executives from 27 firms that are members of the MSI was used.

Average three respondents from each SBU.

Every firm was represented by just one SBU.

A sample of 1099 senior executives from multiple industries in New Zealand.

Response rate: $45 \%$.

Senior Manager Level.

Customer

Orientation,

Competitor

Orientation,

Interfunctional

Coordination, Profit

Orientation,

Intelligence

Generation,

Intelligence

Dissemination,

Response Design, and Response

Implementation.

Preliminary Work: 4 marketing professors and 6 insurance sector managers in Belgium.

2 professors and 6 insurance experts in Spain.

Samples: 76 private Belgian insurance companies.

Response rate: 34/76.

104 private Spanish insurance companies.

Response rate: 32/104.
A 9-item scale.

Overall Reliability: .96.

Customer Understanding

Orientation (.88)

Customer Satisfaction

Orientation (.95)

Competitive Orientation (.94).

10-item, 5-point summary scale.

Overall Reliability: .89.

More parsimonious and managerially-oriented.

The scales by Narver and Slater (1990), Kohli et al. (1993), and Deshpandé et al. (1993) were compared and refined.

This scale was used by Baker et al. (1999).

A 20-item market orientation scale.

Customer Orientation (.74)

Competitor Orientation (.79)

Interfunctional Co-ordination (.77)

Responsiveness (.66)

Profit Emphasis (.83)

The final scale covers three constructs from Narver and Slater (1990), one construct from Jaworski and Kohli (1993), and one construct from Deng and Dart (1994).

A 36-item, 11-point scale.

Overall Reliability: .88 for Belgium, and .87 for Spain.

Analysis of the Final Client

Analysis of the Distributor

Analysis of the Competitors

Analysis of the Environment

Interfunctional Co-ordination

Strategic Actions on Final

Customers

Strategic Actions on

Intermediary Customers

(Distributors)

Strategic

Actions on 
Marketing manager (46\%).

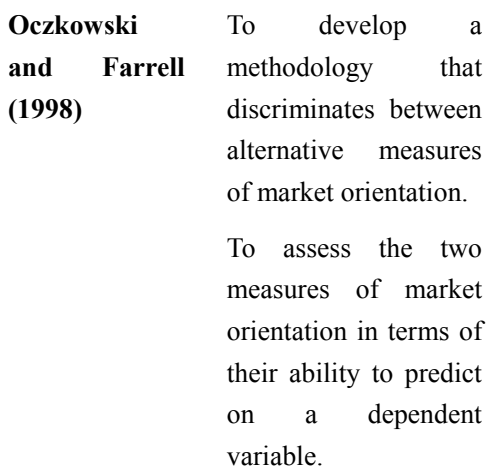

Cadogan et al. To develop and (1999)

Matsuno and To develop a richer Mentzer (2000)
Sample I: 861 publicly-traded companies from the $D \& B$.

Response rate: $29.2 \%$.

Sample II: 1164 privately-owned companies from the $D \& B$ in Australia.

Response rate: $17.1 \%$.

Corporate/Top Management Level (CEO/General Manager).

\section{Sample I: 1327 UK exporters.}

Response rate: $15 \%$.

Sample II: 231 Dutch exporters Response rate: $46 \%$. validate a measure of export market orientation.
Export Intelligence Generation, Export Intelligence

Dissemination,

Export Intelligence

Responsiveness

(Behavioral

Components), and

Coordinating

Mechanisms

Integrative

Component).

300 marketing executives of manufacturing companies in the U.S.

instrument on the basis of the market orientation scale suggested by Jaworski and Kohli (1993).
Competitors

Strategic Actions on the Macro-Environment.

MKTOR outperforms MARKOR:

MKTOR is more superior in explaining variations in measures of performance.

MKTOR with the Cronbach's alphas of .921 and .905 has a greater reliability than MARKOR with the Cronbach $=\mathrm{S}$ alphas of .868 and .884 .

Export Market Orientation.

Based on the integration of the conceptualizations of market orientation suggested by Narver and Slater (1990), and Kohli and Jaworski (1990).

(an Some of the measurement items were based on the scales developed by Jaworski and Kohli (1993), and Narver, Jacobson, and Slater (1993).

A 22-item market orientation scale.

Overall Reliability: .84.

Intelligence Generation (IG) (.66)

Intelligence Dissemination (ID) (.78)

Responsiveness (RESP) (.74).

Homburg and To develop and Pflesser (2000)

validate

Preliminary Work: A content

measurement model of the market-oriented organizational culture. analysis of 50 published reports, and field interviews with 10 managers.

Layers

Market-Oriented

Organizational

Culture: $\quad$ Shared

Basic Values

Pretest: 9 managers and 2 Supporting Market academicians.

Survey: 1100 managers in 1100 SBUs from five industries in Germany.

Response rate: $15.7 \%$

Managerial Level (General

\section{Orientation, Norms} for Market

Orientation, Artifacts of Market Orientation, and Market-oriented Behaviors. market-oriented

organizational culture scale.

A 78-item scale.

Market-oriented Values (.71)

Market-oriented Norms (.72)

Artifacts That Indicate a High Level of Market Orientation (.51)

Artifacts That Indicate a Low Level of Market Orientation (.58) 
managers, marketing managers, and managers from other functional units).

Matsuno et al. To conceptually and (2005) empirically compare three different scales of market orientation: Kohli and Jaworski (1990), Narver and Slater (1990) and a newly developed Extended Market Orientation (EMO) scale.

Ward,

To validate Narver and

Girardi, and Slater (1990)'s

Lewandowska measure of market o (2006) orientation using structural equation modeling (SEM).

Modi and To apply the MKTOR Mishra (2010) scale to nonprofit organizations and build a reliable and valid scale of the market orientation for the non-profit sector (NPMO).

Modi (2012) To construct a parsimonious, valid scale using the previous 21- item market orientation scale (NPMO) in the context of nonprofit organizations.

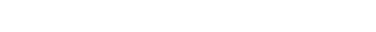

The EMO scale was developed using a combination of exploratory qualitative in-depth interviews (a total of 12 business executives), a review of the

market orientation literature and two survey pretests of the

scale (300 marketing executives for Pretest 1 and 1000 for

Pretest 2 of 3300 manufacturing companies in the U.S.).

In order to compare three scales, the remaining $2000 \quad$ marketing executives from the original mailing list were randomly assigned to one of these scales.

A sample of 217 responses from firms operating in four countries: Australia (81 cases), Singapore (79 cases), China (16 cases), and the Netherlands (41 cases).

A pilot study of the questionnaire with a 20 senior executives from various nonprofit companies was conducted prior to data collection.

The data used for scale development was gathered from a sample of 211 engaged in non-profit and rural development activities.

The data was gathered from 579 nonprofit organizations that deliver community services in India. The data was collected via mail survey. Indian organizations that were

Intelligence

Generation

Intelligence

Dissemination

Responsiveness to

the Intelligence

Extended Scope of

Market Factors:

Customers

Competition

Suppliers

Regulatory Factors

Social/Cultural

Trends

Macroeconomic

Environment.

Customer

Orientation

Competitive

Orientation

Interfunctional

Coordination

Long-Term Horizon

Profit Emphasis.

Donor orientation

Peer orientation

Beneficiary

orientation

Interfunctional

coordination

The scale was based on four dimensions:

Donor orientation

Peer orientation

Beneficiary

orientation

Interfunctional

coordination

A conceptual framework was proposed.
Market-oriented

Behaviors

(.59).

Based on the results related to scale reliability, unidimensionality and construct domain, no single scale was found satisfactory.

.

Customer Orientation (6 items) (0.86) Competitive Orientation (4 items) (0.82)

Interfunctional Coordination (5 items) (0.78)

Long-Term Horizon (3 items) (0.64)

Profit Emphasis (3 items) (0.66).

Initial 35 items of the construct were reduced to 21 items after the analysis.

Donor orientation (.79), Peer orientation (.79), Beneficiary orientation (.64), Interfunctional coordination (.81)

Overall reliability for NPMO (.82)

A 14-item market orientation scale which is parsimonious and efficient.

Donor orientation 0.82

Peer orientation 0.83

Beneficiary orientation 0.84

Interfunctional coordination 0.50

IMO was based on The conceptual framework the three dimensions: proposed was not tested in this Responsiveness to study. 


\begin{tabular}{|c|c|c|c|c|}
\hline (2015) & $\begin{array}{l}\text { orientation (IMO) of a } \\
\text { firm. }\end{array}$ & & $\begin{array}{l}\text { Information, } \\
\text { Dissemination of } \\
\text { Information, } \\
\text { Internal Information } \\
\text { Generation }\end{array}$ & \\
\hline Jangl (2016) & $\begin{array}{l}\text { To validate the } \\
\text { Modified Market } \\
\text { Orientation Scale } \\
\text { (MMOS) which } \\
\text { consists of four } \\
\text { dimensions and } 12 \\
\text { items in the German } \\
\text { high-tech context. }\end{array}$ & $\begin{array}{l}\text { The data was collected from a } \\
\text { sample of } 374 \text { business and } \\
\text { marketing managers of German } \\
\text { high-tech companies in the } \\
\text { manufacturing industry. }\end{array}$ & $\begin{array}{l}\text { Customer } \\
\text { Intelligence } \\
\text { Generation, } \\
\text { Competitor } \\
\text { Intelligence } \\
\text { Generation, } \\
\text { Intelligence } \\
\text { Dissemination and } \\
\text { Integration, } \\
\text { Responsiveness to } \\
\text { Market Intelligence }\end{array}$ & $\begin{array}{l}\text { A 7-point Likert scale was used. } \\
\text { Customer Intelligence } \\
\text { Generation (.75), Competitor } \\
\text { Intelligence Generation (.80), } \\
\text { Intelligence Dissemination \& } \\
\text { Integration } \\
\text { Responsiveness to Market } \\
\text { Intelligence (.74) }\end{array}$ \\
\hline
\end{tabular}

\subsection{Comparison and Criticism of Market Orientation Scales}

A stream of research on market orientation measurement scales has focused on making a comparison or criticism of the extant measurement scales (e.g, Deshpandé \& Farley, 1996; Oczkowski \& Farrell, 1998; Wrenn, 1997). However, the number of comparison/criticism studies of the market orientation scales has been limited to date. These studies either criticized or made comparisons of various measures of the market orientation construct (e.g., Oczkowski \& Farrell, 1998). These studies have mostly compared or criticized the two major market orientation scales developed by Narver and Slater (1990) and Kohli et al. (1993). Unfortunately, other than the insights provided by these studies, there is not much guiding information for researchers on how to select the best possible scale (with acceptable psychometric properties) among multiple scales of the same construct (Oczkowski \& Farrell, 1998). Even though the number of the market orientation scales has increased considerably over the years, there is still a lack of research on how to discriminate between the various measurements of market orientation.

Kohli et al. (1993) recognized MKTOR as being the most comprehensive one, with many positive characteristics. However, they criticized it in terms of its theoretical foundation. According to them, the MKTOR scale has three shortcomings. First, it follows a focused view of markets by focusing on customers and competitors and by ignoring the additional factors (e.g., technology, regulation etc.) that influence customer needs and preferences. Second, it fails to explain the speed with which market intelligence is generated and disseminated within the organization. Finally, it does not cover specific activities and behaviors representing a market orientation in an organization (Kohli et al., 1993).

On the other hand, the MARKOR scale is criticized for focusing too much on intelligence generation and dissemination, and giving a very narrow conceptualization of a market orientation. Also, this conceptualization of a market orientation does not comprehend necessary measures that best reflect the basics of generating value to customers (Pelham, 1993; Oczkowski \& Farrell, 1998, p.362). Pelham (1993) questioned the theoretical background of the MARKOR scale, and viewed the MKTOR scale as superior to the MARKOR scale in terms of reliability and the generation of a simple structure (also see Oczkowski \& Farrell, 1998). However, Kara, Spillan, and DeShields (2005) tested the MARKOR scale over a sample of small -sized service retailers and concluded that the MARKOR scale provided a good measure of market orientation in their research setting.

The conflicting views on the reliability and validity of the two widely-used scales have created the need for further empirical research. The study by Oczkowski and Farrell (1998) was aimed at fulfilling this important need and void in the literature. The authors tried to develop a methodology that discriminates among alternative measures of the market orientation construct, including MKTOR and MARKOR. They assessed these scales in terms of their ability to predict a dependent variable (i.e., business performance). In other words, they used criterion or concurrent validity as a guide in the selection of the measures (Oczkowski \& Farrell, 1998). Business performance was measured with customer retention, new product success, sales growth, return on investment, and overall performance. The independent variables utilized included market orientation, relative size, relative cost, ease of entry, supplier power, buyer power, market growth, competitive intensity, market turbulence, and 
technological turbulence. For the analysis, two sampling frames were utilized. One sample consists of 861 publicly-traded companies from the Dun and Bradstreet. The other contained 1164 privately-owned companies from the Dun and Bradstreet in Australia. The survey was conducted at the corporation level. The key informant was the CEO/General Manager. Response rates of $29.2 \%$ for publicly-listed and $17.1 \%$ for privately-owned companies were reached (Oczkowski \& Farrell, 1998). The study results showed that the MKTOR scale outperformed the MARKOR scale. MKTOR was found to be superior in explaining variations in measures of business performance (Oczkowski \& Farrell, 1998). MKTOR with the Cronbach's alphas of 0.921 and 0.905 has a greater reliability than MARKOR with the Cronbach's alphas of 0.868 and 0.884 . This means that MKTOR provides more consistent or similar market orientation scores than MARKOR across different samples. But, there was a possibility that the continuous use of non-nested tests with OLS regression and summated scales may have distorted or masked the true performance of measurement scales (Oczkowski \& Farrell, 1998). The results of this study should be interpreted with caution, since the results come from only one empirical study.

More empirical testings are necessary to confidently conclude that MKTOR is better than MARKOR or vice versa. Ward et al. (2006) attempted to validate the MKTOR scale in a multiple-country context using structural equation modeling (SEM). They concluded that the MKTOR measure is more likely a collection of three separate measures rather than having the one dimension encompassing the 15 items as suggested by Narver and Slater (1990). They argued that this result might explain the conflicting results in some studies since the individual impact of customer and competitive orientation on performance has not been investigated in most of these studies. Modi and Mishra (2010) applied the MKTOR scale to non-profit organizations and constructed a reliable and valid scale of the market orientation using a sample of 211 Indian nonprofits. This scale was labelled as NPMO (nonprofit market orientation). Later, Modi (2012) refined this 21-item scale and developed a 14-item, more parsimonious scale. The data for this study was obtained from 579 nonprofit organizations that delivered community services in India. This scale was found to be free of the adverse effects of social desirability and common method biases. Jangl (2016) validated a shortened, 12-item version of the Modified Market Orientation Scale (MMOS) using a sample of 374 business and marketing managers from German high-tech companies in the manufacturing industry. This scale was mainly derived from the scales from Kohli et al. (1993), Narver and Slater (1990), and Mohr, Sengupta, and Slater (2014).

\section{Conclusions and Roadmap for Future Research}

Several conclusions have been drawn based on the review of the research on the definition / conceptualization and measurement of market orientation. Also, a number of suggestions for future research were made in relation to the conclusions drawn from this review: First, it was determined that throughout the literature a set of different terms have been used interchangeably to address a market orientation. The terms such as marketing orientation, the marketing concept, market-oriented, market-driven, customer orientation, customer focus, customer-led, customer-focused, customer-oriented, and customer-centric are often used synonymously. Using different terms to address the same concept has caused confusion among scholars and complicated the understanding of the scope of a market orientation. Researchers need to be careful in their selection of terms to address market orientation. They should select and use the terms that best represent the domain of a market orientation.

Second, even though there is no consensus on the definition of market orientation among scholars, the proposed definitions of market orientation have some mutual characteristics. Although there is no single definition that scholars appear to be agreed on, the definitions of market orientation that were suggested by Kohli and Jaworski (1990), and Narver and Slater (1990 have been widely-accepted and frequently-cited by marketing scholars throughout the literature. However, the future research still needs to work on developing a more precise definition of market orientation that consolidates the proposed definitions of market orientation.

Third, a group of researchers suggested broadening the scope of the market orientation construct to include proactive responsiveness or market insight or the driving markets concept (e.g., Chandy \& Tellis, 1998; Jaworski \& Kohli, 1996; Jaworski, Kohli, \& Sahay, 2000; Narver et al., 2004). The future research should look into this issue more closely.

Fourth, the earliest, reliable, comprehensive, multi-item measures of market orientation were developed by Narver and Slater (1990) and Jaworski and Kohli (1993). These two scales are well-accepted by scholars and frequently-used in empirical studies pertaining to market orientation. Many market orientation studies adopt one of these scales and try to validate it in different business or geographic settings. These two scales also serve as a basis for the development of more refined scales. The research in this area has been directed toward developing more parsimonious market orientation scales. Certainly, there is a pressing need for developing more 
parsimonious and generalizable scales that can be used by marketing executives in assessing their companies' degree of market orientation and identifying problematic areas in the application of market orientation (Gray et al., 1998). Future research should focus on developing more parsimonious scales that have potential for global and inter-industry applications.

Fifth, the behavioral/activities/process and cultural perspectives on market orientation complement one another rather than being alternative to each other. According to Deshpandé (1999, p.6), a market orientation can be viewed at three levels: a culture (the shared set of values and beliefs regarding putting customers first), a strategy (creating continuously superior value for a firm's customers), and a series of tactics (the set of cross-functional processes and activities directed as creating and satisfying customers). Viewing a market orientation as a combination of culture, strategy and tactics can help researchers eliminate the division between the behavioral/activities/process and cultural perspectives of market orientation and enable them to examine these two perspectives under the same construct.

Finally, all of the scales developed so far have some shortcomings along with some advantages. There are no simple criteria that could be used by researchers to understand whether any one measurement scale is superior to others. The existent scales of market orientation should be contrasted in terms of their superiority in predicting a dependent variable and in terms of their applicability to various business and nonbusiness contexts. What has been done in this regard thus far is not sufficient and more research is needed.

\section{References}

and Practice, 17(3), 216-224. https://doi.org/10.3846/btp.2016.643

Atuahene-Gima, K. (1995). An exploratory analysis of the impact of market orientation on new product performance: A contingency approach. The Journal of Product Innovation Management, 12(4), 275-293. https://doi.org/10.1016/0737-6782(95)00027-q

Au, A. K. M., \& Tse, A. C. B. (1995). The effect of marketing orientation on company performance in the service sector: A comparative study of the hotel industry in Hong Kong and New Zealand. Journal of International Consumer Marketing, 8(2), 77-87. https://doi.org/10.1300/j046v08n02_06

Baker, W. E., \& Sinkula, J. M. (1999). The synergistic effect of market orientation and learning orientation on organizational performance. Journal of the Academy of Marketing Science, 27(4), 411-427. https://doi.org/10.1177/0092070399274002

Barksdale, H. C., \& Darden, B. (1971). Marketers' attitudes toward the marketing concept. Journal of Marketing, 35, 29-36. https://doi.org/10.2307/1250454

Cadogan, J. W., Diamantopoulos, A., \& Mortanges, C. P. (1999). A measure of export market orientation: Scale development and cross-cultural validation. Journal of International Business Studies, 30(4), (Fourth Quarter), 689-707. https://doi.org/10.1057/palgrave.jibs.8490834

Caruana, A., Ramaseshan, B., \& Ewing, M. T. (1998). The market orientation-performance link: Some evidence from the public sector and universities. Journal of Nonprofit \& Public Sector Marketing, 6(1), 63-82. https://doi.org/10.1300/j054v06n01_05

Chandy, R. K., \& Tellis, G. J. (1998). Organizing for radical product innovation: The overlooked role of willingness to cannibalize. Journal of Marketing Research, 15(November), 474-487. https://doi.org/10.2307/3152166

Christensen, C. M., \& Bower, J. L. (1996). Customer power, strategic investment, and the failure of leading firms.

Cravens, D. W. (1998). Implementation strategies in the market-driven strategy era. Journal of the Academy of Marketing Science, 26(3), 237-241. https://doi.org/10.1177/0092070398263005

Cravens, D. W., Greenley, G., Piercy, N. F., \& Slater, S. F. (1998). Mapping the path to market leadership: Effectively combining various dimensions of strategy in to an integrated process of strategic analysis and action maps the path to market leadership. Marketing Management, 7(3), 29-39.

Day, G. S. (1990). Market driven strategy: Processes for creating value. New York: The Free Press.

Day, G. S. (1994). The capabilities of market-driven organizations. Journal of Marketing, 58(4), 37-52. https://doi.org/10.2307/1251915

Day, G. S. (1998). What does it mean to be market-driven?. Business Strategy Review, 9(1), 1-14. https://doi.org/10.1111/1467-8616.00051 
Day, G. S., \& Wensley, R. (1988). Assessing advantage: A framework for diagnosing competitive superiority. Journal of Marketing, 52(2), 1-20. https://doi.org/10.2307/1251261

Deng, S., \& Dart, J. (1994). “Measuring Market Orientation: A Multi-Factor, Multi-Item Approach,” Journal of Marketing Management, 10, 725-742. https://doi.org/10.1080/0267257x.1994.9964318

Deshpandé, R., \& Farley, J. U. (1996). Understanding market orientation: A prospectively designed meta-analysis of three market orientation scales. Marketing Science Institute, Working Paper, Report No. 96-125, 1-22. https://doi.org/10.4135/9781452231426.n9

Deshpandé, R., \& Farley, J. U. (1998). Measuring market orientation: Generalization and synthesis. Journal of Market-Focused Management, 2, 213-232. https://doi.org/10.1023/a:1009719615327

Deshpandé, R., \& Farley, J. U. (1999). Corporate culture and market orientation: Comparing Indian and Japanese firms. Journal of International Marketing, 7(4), 111-127.

Deshpandé, R., \& Webster, F. E. Jr. (1989). Organizational culture and marketing: Defining the research agenda. Journal of Marketing, 53(January), 3-15. https://doi.org/10.2307/1251521

Deshpandé, R., ed. (1999). Developing a market orientation. Thousands Oaks, CA: Sage Publications. https://doi.org/10.4135/9781452231426

Deshpandé, R., Farley, J. U., \& Webster, F. E. Jr. (1993). Corporate culture, customer orientation, and innovativeness in Japanese firms: A quadrad analysis. Journal of Marketing, 57(January), 23-27. https://doi.org/10.2307/1252055

Dickson, P. R. (1992). Toward a general theory of competitive rationality. Journal of Marketing, 56(January), 69-83. https://doi.org/10.2307/1252133

Dong, X. D., Zhang, Z., Hinsch, C.A., \& Zou, S. (2016). Reconceptualizing the elements of market orientation: A process-based view. Industrial Marketing Management, 56, 130-142. https://doi.org/10.1016/j.indmarman.2015.12.005

Gray, B., Matear, S., Boshoff, C., \& Matheson, P. (1998). Developing a better measure of market orientation. European Journal of Marketing, 32(9/10), 884-903. https://doi.org/10.1108/03090569810232327

Greenley, G. E. (1995). Forms of market orientation in UK companies. Journal of Management Studies, 32(1), 47-66. https://doi.org/10.1111/j.1467-6486.1995.tb00645.x

Gyepi-Garbrah, T. F., \& Asamoah, E. S. (2015). Towards a holistic internal market orientation measurement scale.

Hamel, G., \& Prahalad, C.K. (1994). Competing for the future. Boston, MA: Harvard Business School Press.

Han, J. K., Kim, N., \& Srivastava, R. K. (1998). Market orientation and organizational performance: Is innovation a missing link?. Journal of Marketing, 62(4), 30-45. https://doi.org/10.2307/1252285

Homburg, C., \& Pflesser, C. (2000). A multiple-layer model of market-oriented organizational culture: Measurement issues and performance outcomes. Journal of Marketing Research, 37(November), 449-462. https://doi.org/10.1509/jmkr.37.4.449.18786

Hunt, S. D., \& Morgan, R. M. (1995). The comparative advantage theory of competition. Journal of Marketing, 59(2), 1-15. https://doi.org/10.2307/1252069

Jangl, P. (2016). Model of market orientation of high-tech firms in Germany: Validation study. Business: Theory

Jaworski, B. J., \& Kohli, A. K. (1993). Market orientation: Antecedents and consequences. Journal of Marketing, 57(July), 53-70. https://doi.org/10.2307/1251854

Jaworski, B. J., \& Kohli, A. K. (1996). Market orientation: Review, refinement, and roadmap. Journal of Focused Management, 1(2), 119-135. https://doi.org/10.1007/bf00128686

Jaworski, B. J., Kohli, A. K., \& Sahay, A. (2000). Market-driven versus driving markets. Journal of the Academy of Marketing Science, 28(1), 45-54. https://doi.org/10.1177/0092070300281005

Journal of Strategic Marketing, 23(3), 273-284. https://doi.org/10.1080/0965254x.2014.931877

Kara, A., Spillan, J. E., \& DeShields, O. W. (2005). The effect of a market orientation on business performance: A study of small - sized service retailers using MARKOR scale. Journal of Small Business Management, 43(2), 105-118. https://doi.org/10.1111/j.1540-627x.2005.00128.x

Kohli, A. K., \& Jaworski, B. J. (1990). Market orientation: The construct, research propositions, and managerial 
implications. Journal of Marketing, 54, 1-18. https://doi.org/10.2307/1251866

Kohli, A. K., Jaworski, B. J., \& Kumar, A. (1993). MARKOR: A measure of market orientation. Journal of Marketing Research, 30(4), (November), 467-477. https://doi.org/10.2307/3172691

Kotler, P. (1977). From sales obsession to marketing effectiveness. Harvard Business Review, 55(November-December), 67-75.

Lado, N., Maydeu-Olivares, A., \& Rivera, J. (1998). Measuring market orientation in several populations: A structural equations model. European Journal of Marketing, 32(1/2), 23-39. https://doi.org/10.1108/03090569810197408

Lawton, L., \& Parasuraman, A. (1980). The impact of the marketing concept on new product planning. Journal of Marketing, 44(January), 19-25. https://doi.org/10.2307/1250030

Maignan, I., Ferrell, O. C., \& Hult, G. T. M. (1999). Corporate citizenship: Cultural antecedents and business benefits. Journal of the Academy of Marketing Science, 27(4), 455-469. https://doi.org/10.1177/0092070399274005

Matsuno, K., \& Mentzer, J. T. (2000). The effects of strategy type on the market orientation-performance relationship. Journal of Marketing, 64(October), 1-16. https://doi.org/10.1509/jmkg.64.4.1.18078

Matsuno, K., Mentzer, J. T., \& Rentz, J. O. (2005). A conceptual and empirical comparison of three market orientation scales. Journal of Business Research, 58(1), 1-8. https://doi.org/10.1016/s0148-2963(03)00075-4

McNamara, C. P. (1972). The present status of the marketing concept. Journal of Marketing, 36(January), 50-57. https://doi.org/10.2307/1250868

Mengüc, B. (1996). The influence of the market orientation of the firm on sales force behavior and attitudes: Further empirical results. International Journal of Research in Marketing, 13, 277-291. https://doi.org/10.1016/0167-8116(96)00011-0

Modi, P. (2012). Measuring market orientation in nonprofit organizations. Journal of Strategic Marketing, 20(5), 447-460. https://doi.org/10.1080/0965254x.2012.689991

Modi, P., \& Mishra, D. (2010). Conceptualising market orientation in non-profit organisations: Definition, performance, and preliminary construction of a scale. Journal of Marketing Management, 26(5-6), 548-569. https://doi.org/10.1080/02672570903485113

Mohr, J. J., Sengupta, S., \& Slater, S. (2014). Marketing of high technology products and innovations. England: Pearson Education Limited.

Narver, J. C., \& Slater, S. F. (1990). The effect of a market orientation on business profitability. Journal of Marketing, (October), 20-34. https://doi.org/10.2307/1251757

Narver, J. C., Slater, S. F., \& MacLachlan, D. L. (2004). Responsive and Proactive Market Orientation and New-Product Success. Journal of Product Innovation Management, 21, 334-347. doi:10.1111/j.0737-6782.2004.00086.x

Oczkowski, E., \& Farrell, M. A. (1998). Discriminating between measurement scales using non-nested tests and two-stage least squares estimators: The case of market orientation. International Journal of Research in Marketing, 15, 349-366. https://doi.org/10.1016/s0167-8116(98)00007-x

Pelham, A. (1993). Mediating and moderating influences on the relationship between market orientation and performance (Unpublished Doctoral Dissertation). The Pennsylvania State University, Pennsylvania, U.S.A..

Peters, T. J., \& Waterman, R. H. (1982). In search of excellence: Lessons from America's best run companies. New York: Harper and Row, Inc.

Raju, P. S., Lonial, S. C., \& Gupta, Y. P. (1995). Market orientation and performance in the hospital industry. Journal of Health Care Marketing, 15(4), 34-41.

Ruekert, R. W. (1992). Developing a market orientation: An organizational strategy perspective. International Journal of Research in Marketing, 9(3), 225-245. https://doi.org/10.1016/0167-8116(92)90019-h

Sargeant, A., \& Mohamad, M. (1999). Business performance in the UK hotel sector- Does it pay to be market oriented?. The Service Industries Journal, 19(3), 42-59. https://doi.org/10.1080/02642069900000029 
Shapiro, B. P. (1988). What the hell is 'market-oriented'?. Harvard Business Review, 66(November-December), $119-25$.

Siguaw, J. A., Brown, G., \& Widing, R. E. II (1994). The influence of the market orientation of the firm on sales force behavior and attitudes. Journal of Marketing Research, 31(1), 106-116. https://doi.org/10.2307/3151950

Siguaw, J. A., Simpson, P. M., \& Baker, T. L. (1998). Effects of supplier market orientation on distributor market orientation and the channel relationship: The distributor perspective. Journal of Marketing, 62(3), 99-111. https://doi.org/10.2307/1251746

Siguaw, J. A., Simpson, P. M., \& Baker, T. L. (1999). The influence of market orientation on channel relationships. In R. Deshpandé (ed.), Developing a market orientation (pp. 267-302). Thousand Oaks, CA: Sage Publications. https://doi.org/10.4135/9781452231426.n11

Slater, S. F., \& Narver, J. C. (1994a). Does competitive environment moderate the market orientation-performance relationship?. Journal of Marketing, 58(January), 46-55. https://doi.org/10.2307/1252250

Slater, S. F., \& Narver, J. C. (1994b). Market orientation, customer value, and superior performance. Business Horizons, (March-April), 22-28. https://doi.org/10.1016/0007-6813(94)90029-9

Slater, S. F., \& Narver, J. C. (1995). Market orientation and the learning organization. Journal of Marketing, 59(3), 63-74. https://doi.org/10.2307/1252120

Slater, S. F., \& Narver, J. C. (1998). Customer-led and market-oriented: Let's not confuse the two. Strategic Management Journal, 19, 1001-1006.https://doi.org/10.1002/(sici)1097-0266(199810)19:10\%3C1001::aid-smj996\%3E3.0.co;2-4

Strategic Management Journal, $\quad 17(3), \quad$ 197-218. https://doi.org/10.1002/(sici)1097-0266(199603)17:3\%3C197::aid-smj804\%3E3.3.co;2-1

Tse, A. C. B. (1998). Market orientation and performance of large property companies in Hong Kong. International Journal of Commerce \& Management, 8(1), 57-69. https://doi.org/10.1108/eb047363

Ward, S., Girardi, A., \& Lewandowska, A. (2006). A cross-national validation of the Narver and Slater market orientation scale. Journal of Marketing Theory and Practice, 14(2), 155-167. https://doi.org/10.2753/mtp1069-6679140205

Webster, F. E., Jr. (1988). The rediscovery of the marketing concept. Business Horizons, (May-June), 29-39. https://doi.org/10.1016/0007-6813(88)90006-7

Workman, J. P. Jr., Homburg, C., \& Gruner, K. (1998). Marketing organization: An integrative framework of dimensions and determinants. Journal of Marketing, 62(July), 21-41. https://doi.org/10.2307/1251741

Wrenn, B. (1997). The market orientation construct: Measurement and scaling issues. Journal of Marketing Theory and Practice, 5(3), 31-54. https://doi.org/10.1080/10696679.1997.11501770

\section{Copyrights}

Copyright for this article is retained by the author(s), with first publication rights granted to the journal.

This is an open-access article distributed under the terms and conditions of the Creative Commons Attribution license (http://creativecommons.org/licenses/by/4.0/). 